Jozef
Laura LACHVANANEROVÁt

Supervisor: Miriam PEKARČÍKOVÁ ${ }^{5}$

DOI: https://doi.org/10.53052/9788366249844.22

\title{
Procesy bizNeSOWE W RAMACH ROZWIĄZAŃ PLM
}

Streszczenie: Prezentowany artykuł wskazuje, że procesy biznesowe są ważną częścią rozwiązań PLM. Tylko PLM zawiera wszystkie niezbędne narzędzia, które pomagają firmom zachować standardy i zasady komunikacji. Opisując przebieg najbardziej złożonego i złożonego procesu w firmach, jakim jest zarządzanie zmianą, zwrócimy uwagę na znaczenie narzędzi PLM w zarządzaniu firmą. W tym artykule dowiesz się również, jak niezbędna jest wzajemna współpraca między branżami, integracja z innymi aplikacjami takimi jak MS Office, $\mathrm{CAD}, \mathrm{CAE}, \mathrm{CAM}$ oraz połączenie z systemami informatycznymi.

Słowa kluczowe: workflow, PLM, zarządzanie zmianą, integracja

\section{BUSINESS PROCESSES AS A PART OF PLM SOLUTIONS}

Summary: The presented article points out that business processes are an important part of PLM solutions. Only PLM includes all the necessary tools that help companies maintain their standards and rules of communication. By describing the course of the most complex and complex process in companies, i.e. change management, we will point out the importance of PLM tools in company management. You will also learn in this article how necessary mutual cooperation between industries, integration with other applications such as MS Office, CAD, CAE, CAM and connection with information systems.

Keywords: workflow, PLM, change management, integration

\footnotetext{
${ }^{1}$ Technical University of Kosice, Faculty of Mechanical Engineering, Department of Industrial and Digital Engineering; jozef.trojan@tuke.sk

${ }^{2}$ Technical University of Kosice, Faculty of Mechanical Engineering, Department of Industrial and Digital Engineering; peter.trebuna@tuke.sk

${ }^{3}$ Technical University of Kosice, Faculty of Mechanical Engineering, Department of Industrial and Digital Engineering; marek.kliment@tuke.sk

${ }^{4}$ Technical University of Kosice, Faculty of Mechanical Engineering, Department of Industrial and Digital Engineering; laura.lachvajderova@tuke.sk

5 doc. Ing. PhD., Technical University of Kosice, Faculty of Mechanical Engineering, Department of Industrial and Digital Engineering; miriam.pekarcikova@tuke.sk
} 


\section{Introduction}

Business processes represent a set of processes called Workflows that accompany the creation and design of a product from concept to end of life. These processes are very specific according to the nature of the company and the type of products. Typical representatives of these processes are e.g. Approval processes within the company, where the document, production documentation or other information is the subject of assessment, approval, authorization by one or more persons (Fig.1).

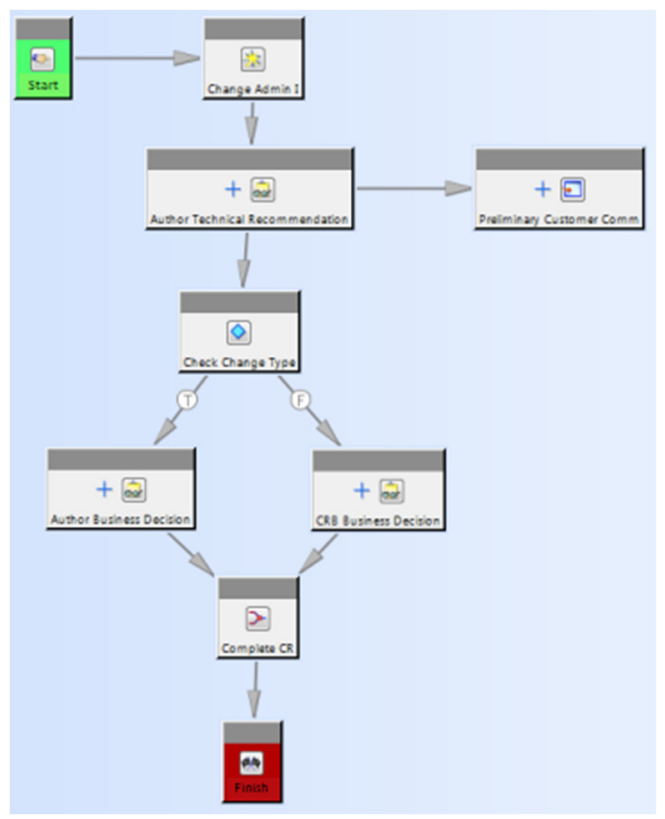

Figure 1. Workflow example [1]

Business processes are part of PLM solutions, because only PLM offers all the necessary tools to maintain corporate standards and rules of communication between individual departments or entire companies in a corporate setting. Once all business processes related to the development and management of production data and information are converted to electronic form, it is then easy to use user and group permissions and roles to keep all processes running according to uniform rules, which cannot be bypassed as in the absence of PLM solutions. Existing company guidelines or unified procedures are optimized during the implementation of PLM solutions for the most efficient course, also with regard to the possible disappearance of some existing jobs [2].

\section{Change Management}

Change management is the most complex and therefore the most complex process in companies, due to the fact that its initiation and coordination is influenced by many factors throughout the course of change management. Change management runs 
throughout the company, and the role of the change management coordinator or administrator is therefore absolutely necessary for its proper course. The change procedure in the PLM solution usually follows the CMII methodology, which is recognized as an international standard. The change can be initialized by the customer, innovations within the company, an error in the documentation, etc. It can be simple, relating to only one component/item, but even with a high degree of unification, a simple change can cause a complex process, as an item can enter several final products with different production lead times, different series and the like. However, the change can also be very complex, extending to the definition of means of production. For these reasons, it is necessary to distinguish between several stages of change management. Initialization of the change is represented by change reports (PR), followed by a change request (CR) with a proposal for a specific solution, this is then sent by the change notice $(\mathrm{CN})$ sent to the responsible department for assessment. It is necessary to assess all the effects of the change and evaluate its implementation with regard to the costs incurred. This is where the power of the PLM solution comes into play, because with its help it is possible to find out all the impacts that change very effectively and in a short time, and thus it is possible to estimate the costs of implementing the change relatively accurately [3].

PLM change management is very often linked to change management in an enterprise information system and there is a need for mutual coordination. Thanks to the characteristic feature of PLM processes, i.e. the possibility of data distribution during change management to persons who are its participants, the need to find information for all participants is eliminated and the capabilities of processes in submitting PLM solutions are fully manifested here (Fig.2).

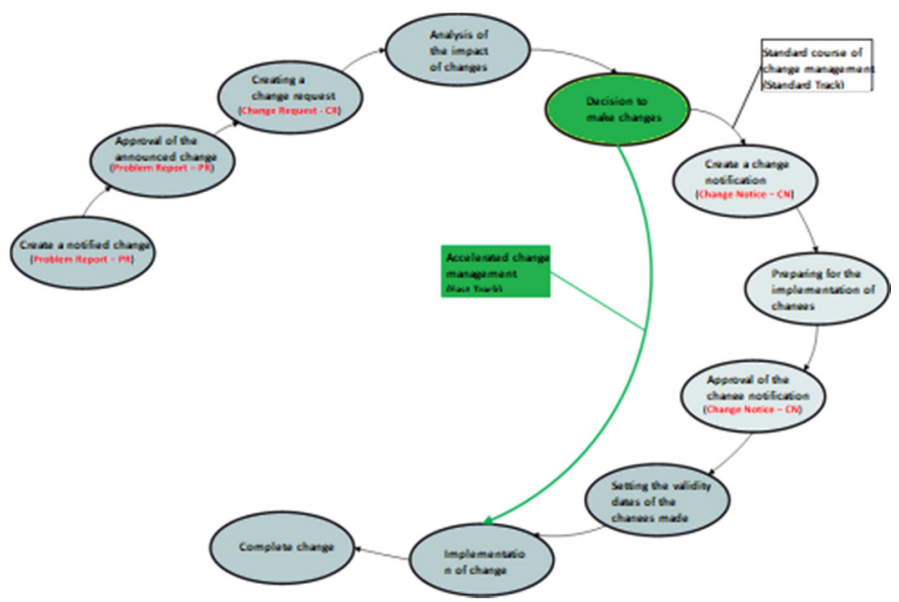

Figure 2. The course of change management [4]

Nowadays, when companies are forced to constantly reduce production and development costs in order to remain competitive, companies are often faced with the decision of which parts to produce for their products and which to buy with regard to their production technology. Therefore, there are supply chains, cooperation with external partners, cooperation. Furthermore, the international corporate organization of companies is also common. All these forms of collaboration require information 


\section{Jozef TROJAN, Peter TREBUŇA, Marek KLIMENT, Laura LACHVAJDEROVÁ}

sharing. Companies without PLM solutions solve this cooperation primarily by e-mail communication, offline data exchange, often also in paper form, through the necessary personal negotiations under. These forms of cooperation often lead to the late distribution of information, often outdated data, which in turn can lead to financial losses, late deliveries of goods, etc. If a PLM solution exists, there are tools that directly solve the above-mentioned problems with the controlled distribution of the necessary documentation. Thanks to web technologies and, for example, the already mentioned 4-layer architecture of PLM solutions, it is no longer a problem to allow external partners access to the corporate infrastructure, and thus also the data managed by the PLM solution [5].

Of course, it is necessary to differentiate the level of approach according to the importance and role of the partner. The scope and level of authorization can directly control the possibilities of access, so as to prevent the leakage of company know-how, but at the same time external users have access to the required information (Fig.3).

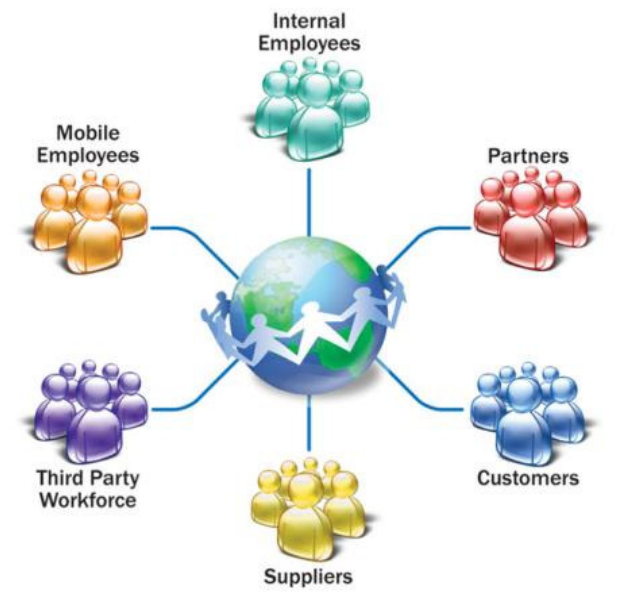

Figure 3. Mutual cooperation in information and data sharing [6]

This approach may require the direct existence of a PLM client on the external partner's side, or just access to a web portal where the necessary data is shared. An example of this cooperation is typically the automotive and aerospace industries, which outsource the production of parts in this way, but often also the development of the part itself on the basis of specifications and assembly models.

\section{Integration with MS Office, CAD, CAE and CAM}

Given the prevalence and use of Microsoft Office software packages in companies, there is a logical need not only to be able to manage data obtained in these office applications - such as Microsoft Word, Excel, PowerPoint and others, but also to allow the user to directly integrate these products/software with PLM solutions. , and thus without the need to run a client PLM solution to easily create, store and edit documents of the above applications through an extended menu of the applications themselves. Then these applications can be used directly as sources and from the moment the 
document is created, it is managed by a PLM solution without the need to import data and the like. Depending on the degree of integration of these products, for example, the mail client can be connected to the PLM solution and the tasks received within the PLM solution that users can receive through business processes can then be directly managed and participate in these processes directly with the MS Outlook mail client environment [7].

If the core of every PLM solution is product lifecycle management, then CAD integration is an essential part of these PLM solutions, because without this it would not be possible to manage and control product technical documentation, both $2 \mathrm{D}$ and $3 \mathrm{D}$ documentation. As a rule, each integration/interface has the following basic functionalities for cooperation with PLM solutions: Data storage and management, Creation and management of BOMs, Versioning of documentation, and Search for existing data. Most PLM solutions support multiple CAD systems and address their integration and data management. However, few PLM solutions are able to manage data obtained from various CAD systems - Multi-CAD environments. This capability has recently been playing an increasingly important role in choosing the right PLM solution for a company. This fact is due to the need to share and exchange data between companies due to cooperation, collaboration and the like. It is often an exchange of data between different CAD systems, and therefore there is a need for the ability of PLM solutions to manage data from different CAD systems in a single environment so that the user is not burdened by the need to convert to universal formats such as. STEP, IGES [8].

Increasingly, virtual/digital product validation is playing an increasingly important role in simulating the product's behavior under load, typical of its application and use. Deployment of these systems can significantly save the cost of building and testing physical prototypes. These are software tools of the FEM finite element method, which use 3D data of structural systems as a data source. Thus, with the use of PLM for CAD data management, it is offered to use a PLM solution also for this FEM data with a view to ensuring the consistency and validity of the content of this data. When using PLM to manage both CAD and FEM data, it is ensured that the correct and current geometry is always used to define the computational model, and any change to the source geometry managed by development/design will also be reflected in the computational model. This fact can therefore fundamentally save the company's costs, given the duration of the calculations, which take several days for complex tasks. The results of these analyzes can then be stored in the PLM in neutral formats so that they are available without the need for special and very expensive software for all PLM users who have to work with this data.

CAM systems, as well as CAE systems, use machining technology for existing 3D data from the design for subsequent processing, where the result is an NC code for one or more machine tools. The reason for using a PLM solution to control and manage these CAM data is the same as in the case of CAE. Again, this is the timeliness and consistency of the source data within a unified PLM environment. Some CAM solutions in cooperation with the PLM solution enable the distribution of the generated $\mathrm{NC}$ code for the respective operation or sequence of operations directly to the machine tool. These definitions of CAM machining often also use uniform sources of production resources within PLM solutions such as machines, jigs, machining tools, their holders, etc. The advantage of this solution is that if there is CAM data for the production of the part, then this data can be automatically stored as a technological 
process, including all production operations with the definition of all necessary production means. This functionality can significantly streamline the work of technology departments. The above functionalities by integrating all CAD / CAE / CAM play an important role in the productivity of work of individual departments of manufacturing companies. Therefore, PLM solutions are increasingly being promoted not only in the development departments of companies for the management of design data but also in other departments of companies.

\section{Connection with information systems}

If the main tasks of PLM solutions are product innovation and development, monitoring and management of product information and configurations throughout their life cycle, management of production processes, a collaboration between engineering departments, then we can say that PLM is data-driven. Unlike enterprise information systems, which manage finance, orders, production order processes, production planning, logistics, and warehousing, we can say here that information systems are transaction-driven. PLM and ERP play different, complementary roles in product innovation and implementation, and therefore their mutual integration helps companies to be more efficient in their activities related to the development and management of the product portfolio [9].

An example of this cooperation is Figure 4, where we can see the mutual sharing of information about the structure of products, items, changes, production information, technological processes, etc. This integration must be parametrically parametric in order to be able to link different data models of PLM and ERP databases and thus enable the sharing of monitored attributes, including the possibility of defining which system is controlling for which attribute and which only shares information [10].

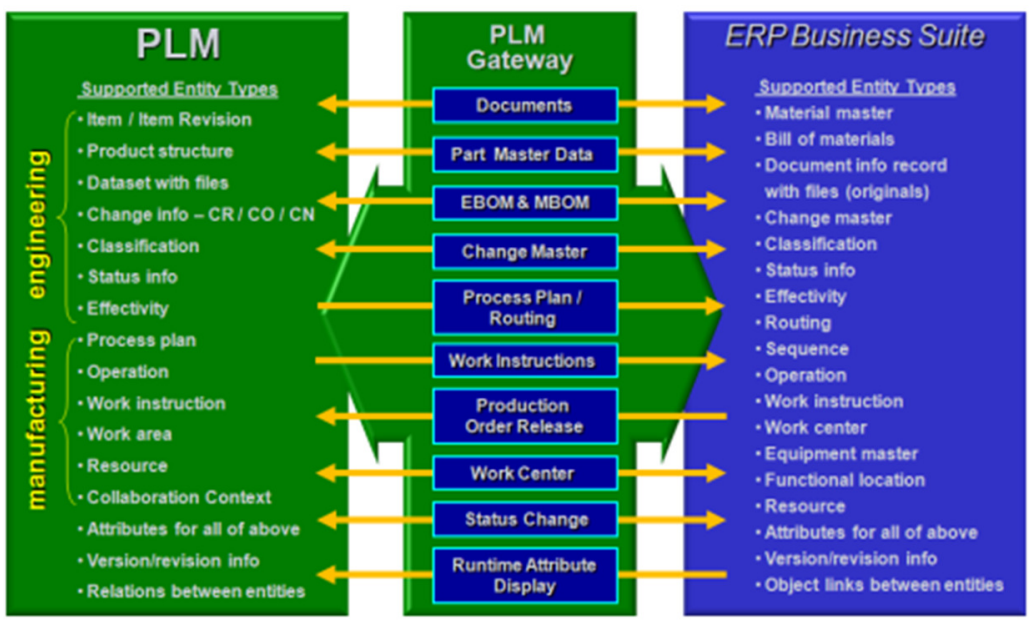

Figure 4. Interface between PLM and ERP data models

The following Figure 5 shows an example of typical product development and documentation process. This process is initialized in PLM but goes across the 
company, so it necessarily intervenes in the field of ERP, where the responsible departments complement the information and manage a process that will take care of the distribution of this information to both systems. Information between the two solutions can be exchanged both offline and online via the program interface/gateway. Because each company is specific to its internal processes, its organization, these interfaces cannot be generalized and only used according to the chosen information system, but they must be minimally configured, but often programmatically modified to achieve the desired form of cooperation with PLM. These software modifications and configurations are usually the most difficult part of implementing PLM solutions.

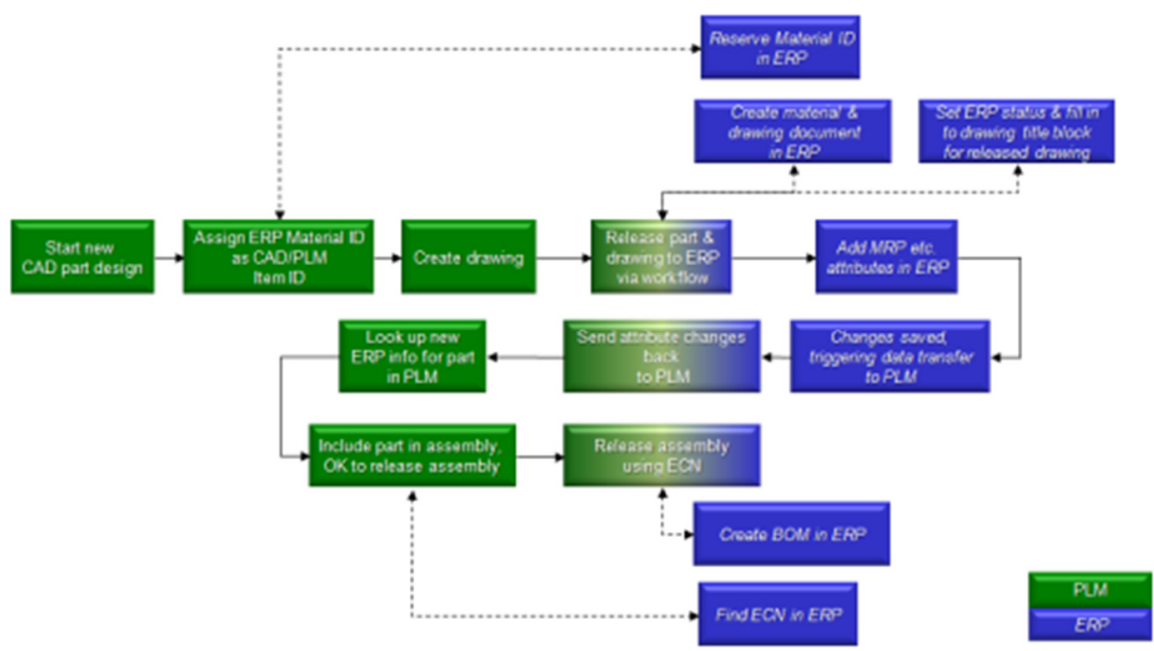

Figure 5. Example of a development process

\section{Conclusion}

As we can see, business processes must be part of the PLM spectrum, because nowadays the processes of companies that are not integrated into PLM are often longer, more error-prone and, most importantly, more expensive. An equally important part is the mutual cooperation between individual market segments, as well as the integration with other existing applications, which accelerate the processes even more and thus the company creates a profit and a competitive advantage.

\section{Acknowledgements}

This article was created by the implementation of the grant project APVV-17-0258 "Digital engineering elements application in innovation and optimization of production flows", APVV-19-0418 "Intelligent solutions to enhance business innovation capability in the process of transforming them into smart businesses", VEGA 1/0438/20 "Interaction of digital technologies to support software and hardware communication of the advanced production system platform”, KEGA 
001TUKE-4/2020 "Modernizing Industrial Engineering education to Develop Existing Training Program Skills in a Specialized Laboratory", VEGA 1/0340/21 "The impact of a pandemic and the subsequent economic crisis on the development of digitization of enterprises and society in Slovakia" and KEGA 009TUKE-4/2020 "Transfer of Digitization into Education in the Study Program Business Management and Economics".

\section{REFERENCES}

1. STRAKA M., KACMARY, P., ROSOVA A., YAKIMOVICH B., KORSHUNOV A.: Model of unique material flow in context with layout of manufacturing facilities, Manufacturing Technology, 16(2016)4, pp. 814-820.

2. DULINA L., EDL M., FUSKO M., RAKYTA M., SULIROVA I.: Digitization in the Technical Service Management System. In: MM Science Journal. 1(2018). p. 2260 - 2266. ISSN 1803-1269.

3. FUSKO M., RAKYTA M., KRAJCOVIC M., DULINA L., GASO M., GRZNAR, P.: Basics of Designing Maintenance Processes in Industry 4.0. In: MM Science Journal. No. March (2018), p. 2252-2259. ISSN 1803-1269.

4. BUČKOVÁ M., KRAJČOVIČ M., EDL M.: Computer Simulation and Optimization of Transport Distances of Order Picking Processes. Procedia Engineering 2017, 192, 69-74. DOI: 10.1016/j.proeng.2017.06.012.

5. STRAKA M., LENORT R., KHOURI S., FELIKS J.: Design of large-scale logistics systems using computer simulation hierarchic structure, International Journal of Simulation Modelling, 17(2018)1, pp. 105-118.

6. PLINTA D., KRAJČOVIČ M.: Production System Designing with the Use of Digital Factory and Augmented Reality Technologies. In Advances in Intelligent Systems and Computing. 350(2016), p. 187-196. ISSN 2194-5357.

7. MANLIG F., SLAICHOVA E., KOBLASA F., VAVRUSKA J.: Innovation of business processes by means of computer-aided simulation: Novel Trends in Production Devices And Systems, Applied Mechanics and Materials, 474(2014), Pages: 67-72, DOI: 10.4028/www.scientific.net/AMM.474.67.

8. GREGOR T., KRAJCOVIC M., WIECEK D.: Smart Connected Logistics. In Procedia Engineering. vol. 192. Transcom $201712^{\text {th }}$ International Scientific Conference of Young Scientists on Sustainable, Modern and Safe Transport. High Tatras, Grand Hotel Bellevue, Slovakia. 31. 05. - 02. 06. 2017. p. 265-270. ISSN 18777058.

9. MARKULIK Š., CEHLÁR M., KOZEL R.: Process approach in the mining conditions / In: Acta Montanistica Slovaca. Roč. 23, č. 1 (2018), s. 46-52. - ISSN 1335-1788 Spôsob prístupu: https://actamont.tuke.sk/ams2018.html.

10. SANIUK S., SAMOLEJOVA A., SANIUK A., LENORT R.: Benefits and barriers of participation in production networks in a metallurgical cluster - research results, Metalurgija, 54(2015)3, 567-570. 